\title{
The Engineering Undergraduates Industrial Training Programme in Malaysia: Issues and Resolutions
}

\author{
Aini Najwa Azmi, Yusri Kamin, Ahmad Nabil Md Nasir, Muhammad Khair Noordin
}

\begin{abstract}
Electrical and electronics is one of the sectors that have led in the process of moving to Industry 4.0 and an important contributor in Malaysia's economy as it is one of the twelve National Key Economic Area (NKEA) in the country's Economic Transformation Program (ETP). Globalization era needs human capital resources with competency, competitive and multi-skilled to lead a country to be a developed country. Malaysia is one of developing country in the world that is facing the unemployment issue among engineering graduates. The delayed of education transformation will affect the graduates' skills developments which can lead to unemployment among them because the demands of today's industries cannot be met. Many employers admit that our engineering graduates lack in non-technical skills, but they seem fine in technical skills. Industrial training is a platform for students to develop nontechnical skills in the real workplace which difficult to be learned in the classroom. All bachelor's engineering students need to undergo industrial training for at least 8 weeks as stated in Engineering Accreditation Council (EAC) manual. This paper presents the issues arise and resolutions done by faculty in minimizing the issues. A qualitative study has been done to twelve industrial training coordinators in 8 public and private universities to find the experts' opinions. Many issues have been highlighted with resolutions to minimize the issues. This is very important to assure students can gain valuable industrial training by effectively developing their non-technical skills to meet the industries demands.
\end{abstract}

Index Terms: industrial training, engineering graduates, nontechnical skills, unemployment, issues

\section{INTRODUCTION}

The curriculum that is designed by Ministry of Higher Education of Malaysia should has the elements that can produce holistic graduates with technical, non-technical skills and good ethics and morality. The non-technical skills which is hard to learn in the universities can be learned effectively during industrial training (Laguador, 2013; Osman et al., 2016; Yusof, Mohd Fauzi, Zainul Abidin, \&

Revised Manuscript Received on April 19, 2019.

Aini Najwa Azmi, Department of Technical and Engineering Education, School of Education, Faculty of Social Sciences and Humanities, Universiti Teknologi Malaysia, Johor Bahru, Johor Darul Takzim, Malaysia.

Yusri Kamin, Department of Technical and Engineering Education, School of Education, Faculty of Social Sciences and Humanities, Universiti Teknologi Malaysia, Johor Bahru, Johor Darul Takzim, Malaysia.

Ahmad Nabil Md Nasir, Department of Technical and Engineering Education, School of Education, Faculty of Social Sciences and Humanities, Universiti Teknologi Malaysia, Johor Bahru, Johor Darul Takzim, Malaysia.

Muhammad Khair Noordin, Department of Technical and Engineering Education, School of Education, Faculty of Social Sciences and Humanities, Universiti Teknologi Malaysia, Johor Bahru, Johor Darul Takzim, Malaysia
Awang, 2013). Industrial training is a part of university curriculum that provide an opportunity for students to apply what they have learn in the lecture class to the real workplace in the industry (Ayob et al., 2013; Bhurtun, Jahmeerbacus, Oolun, \& Feliachi, 1999; Jamil, Shariff, \& Abu, 2013; Phang, Yusof, Saat, \& Yusof, 2014).

Industrial training program is in the academic curriculum in higher education institutions. This training is an opportunity for undergraduate students to incorporate workrelated experience and knowledge into their formal education in a university by taking part in supervised and planned work in real-world professional environments (Renganathan, Ambri, Abdul, \& Li, 2013). Industrial training program can develop students' technical skills, nontechnical skills and good work ethics. Industrial training is a platform for students to gain confidence and face challenges at work such as teamwork, working under pressure and dealing with people from all levels of the organization (Pillai, Khan, Syahirah, \& Raphael, 2012). Through industrial training, students can expose themselves to be as potential future employers, develop real workplace skills and gain a lot of work experience

Today's employers really need engineering graduates who are good in technical skills but in non-technical skills too (Azmi, Kamin, Noordin, \& Nasir, 2018; Noordin, 2014). Non-technical skills are the added values for the engineering graduates to be more employable in the 21 st century industry. This is not meaning that technical skills are not important. It is important for engineering graduates to be equipped with non-technical skills to complement their technical skills (Noordin, 2014).

Table 1: Employers' rating on the importance of nontechnical skills

\begin{tabular}{|l|l|}
\hline Competencies & Weighted Average Rating \\
\hline Critical Thinking/Problem Solving & 4.62 \\
\hline Teamwork/Collaboration & 4.56 \\
\hline Professionalism/Work Ethic & 4.46 \\
\hline Oral/Written Communications & 4.30 \\
\hline Leadership & 3.82 \\
\hline Digital Technology & 3.73 \\
\hline Career Management & 3.46 \\
\hline Global/Multi-cultural Fluency & 3.01 \\
\hline
\end{tabular}

$* 5$-point scale, where 1=Not essential, 2=Not very essential, 3=Somewhat essential, 4=essential, 5=Absolutely essential. Adapted from NACE Job Outlook 2018

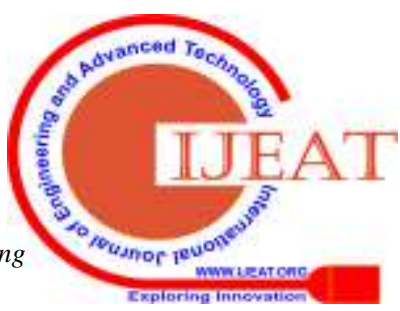


Based on Table 1, employers really emphasize on nontechnical skills in term of qualities of engineering graduates. Recently, critical thinking and problem-solving, teamwork, work ethics and communication skills are the highest four skills that are demanded by employers. As stated in Muhammad Khair \& et al (2016), engineering students can easily grasp the technical skills while studying in university, but there come challenges when preparing them with enough non-technical skills. It becomes to university's responsibility in preparing engineering graduates as demanded by today's employers.

\section{LITERATURE REVIEW}

Entering the professional workplace in the industries, "employers seek graduate employees who are able to transfer their critical thinking abilities to the workplace" (Tapper, 2004). This is the proof that critical thinking that lead to problem solving skill is very important. However, not all fresh engineering graduates in Malaysia can possessed this skill outstandingly. Based on a research done Husain et al., (2013), critical thinking and problem-solving skills are at the below of the ranking compared to teamwork skill which is in the first ranking. However, as reported in NACE Job Outlook (2018), critical thinking and problemsolving skills are the most important based on employers' rating. Critical thinking and problem-solving skills should be emphasized by higher institution because these skills are demanded by today's industry (MOHE, 2006). Furthermore, students feel that their critical thinking and problem-solving skills are good, but the employers in the industries feel that their non-technical skills are at the intermediate level (Husain et al., 2013; Ramlee Mustapha et al., 2008). The gap between students' and employers' perception will give an impending problem for fresh engineering graduates to be hired once they are graduated (Rasul, Abd Rauf, Mansor, \& Puvanasvaran, 2012). Based on Rasul et al (2014), an employee who is high in critical thinking and problemsolving skills according to the employers could demonstrate creative and innovative thinking, able to generate new ideas and able to decide the best alternative. As can be seen in Zaharim, Yusoff, Omar, \& Mohamed (2009)'s gap analysis between perception and expectation of employers towards engineering graduates in Malaysia. The importance of nontechnical skills can be seen clearly in Figure 1.1 when the highest rating went for communication skills when the employers rated $86.7 \%$. Teamwork skills seem to be the second highest with $85.1 \%$ followed by problem-solving skills with $84.6 \%$ respectively. However, competent in application and practice is technical skill where it was ranked in second place after a non-technical skill with $85.5 \%$. This shows that the importance of non-technical skills to be equipped by engineering graduates to be a competent engineer. In addition, as can be found in Rao (2014), a study from the Carnegie Foundation and the Stanford Research Institute reveals that technical skills and knowledge account for about 15 percent of the reason an individual gets a job, keeps the job and advances in that job. The remaining 85 percent of job success is based on the individual's "people skills.".

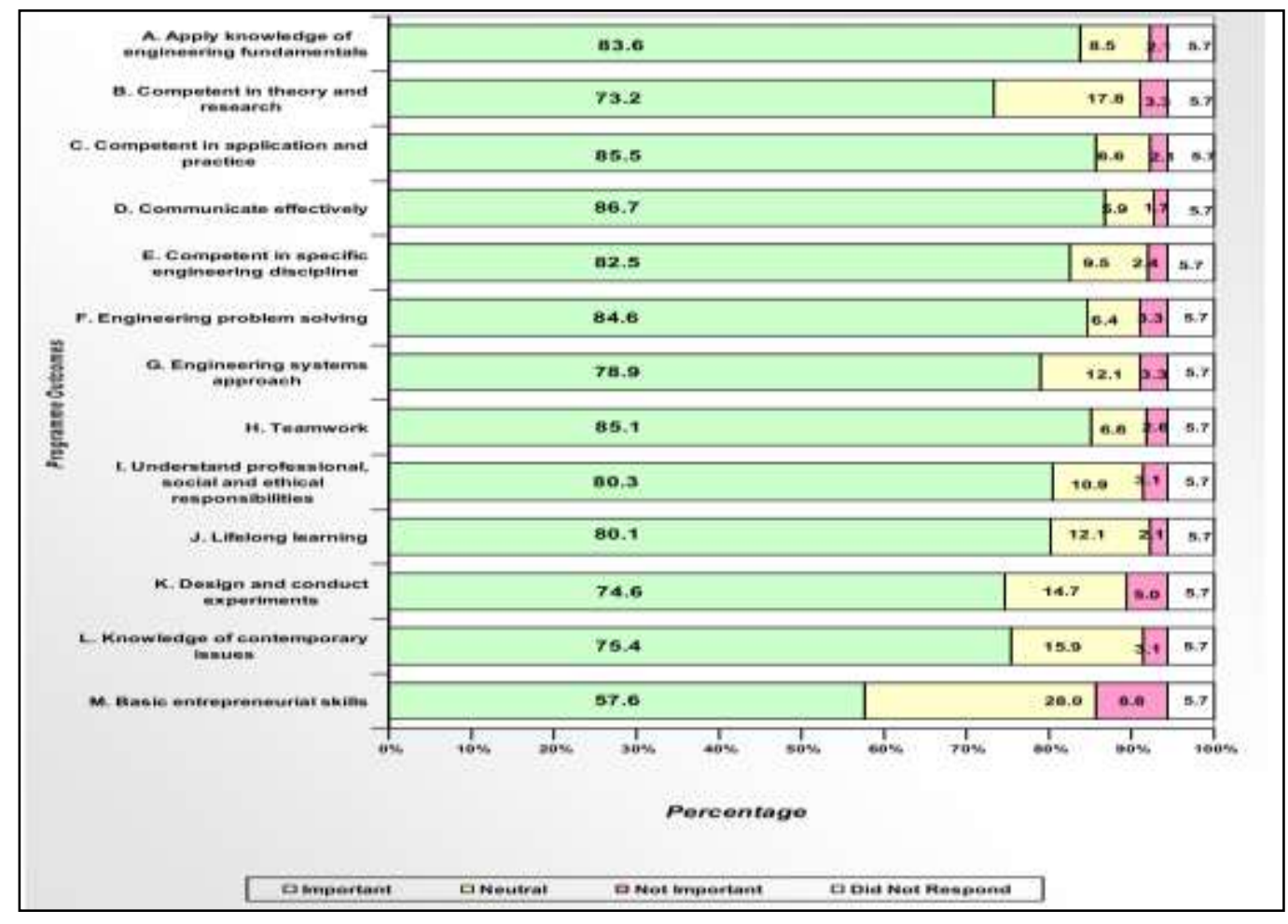

Figure 1: Employers' expectation on technical and non-technical attributes of their engineering workforce 
As mentioned in the previous paraphraph, the lack of nontechnical skills among engineering graduates is hugely related to the unemployment issue among them. Globalization era needs human capital resources with competency, competitive and multi-skilled to lead a country to be a developed country. Malaysia is one of developing country in the world that is facing the unemployment issue among graduates. The unemployment issue among engineering graduates is an issue that cannot be neglected because they are very important to drive the nation to be more innovative and productive high-income economy (Hanapi, Nordin, \& Khamis, 2015). Creative, innovative and productive are the skills that are demanded by IR 4.0 that is already started in Malaysia (www.miti.gov.my). This unemployment issue arises when there is insufficient or inappropriate education and training which does not focus on non-technical skills such as innovation and creativity skills to increase the competency and competitiveness of the workers (Nuwagaba, 2012). A low quality of human capital resource may lead to a slow movement of economy in a country. This is a huge problem in the most of developing country in the world.

Skills, unlike innate abilities, can be learnt and trained. This way, alertness understood as a skill can be learnt through education and further developed in industrial training program (Kucel, Róbert, Buil, \& Masferrer, 2016). Industrial training is a platform for students to get exposed in the real workplace and professional practice. At the same time, students will learn and develop technical and nontechnical skills. Industrial training is the only way for all students to relate the theory learned in the university with practices in the industries. In addition, based on Bhurtun, Jahmeerbacus, Oolun, \& Feliachi, (1999), who were study about industrial training for Electrical and Electronics students, not all engineering practice can be learned in classroom, but they must undergo to real industry to learn the actual engineering practices. Based on Khairiyah et al., (2018), there is an existence of gaps between perceptions and expectation between all stakeholders especially students, universities and industries during industrial training. According to Shariff \& Muhamad (2010) that can be found in Phang, Yusof, Saat, \& Yusof, (2014), there are some weaknesses in the current practice of industrial training. The weaknesses are:

a) insufficient documentation (faculty),

b) no standard procedures and guidelines for industrial training (faculty),

c) absence or no documented industrial training syllabus and scope of industrial training (faculty),

d) objectives and its curricular structure are not clearly defined (faculty),

e) insufficient training evaluation on students and their learning outcomes after completion of training, (faculty) and

f) no standard or formal evaluation from the host company (industry).

It was also commonly heard that trainees were not really learning in the industrial training as they were given menial and clerical tasks and they were treated as extra hands on the job. Based on previous study that can be found in Shariff \& Muhamad (2010), similar studies showed low mean scores on the responsibilities from both host organizations (industries) and the faculties towards industrial training. The trainee complaint that they are received unclear training objectives, scopes, nature of training at the workplace and inadequate evaluation.

The present evaluation in the industrial training program was inadequate as it did not assess the "learning" and "behavioral level" of the students; it was mainly based on significant the evaluation of the trainee's work performance by the supervisors in the industries. The trainees were solely responsible for their own actions and learning (Shariff \& Muhamad, 2010). Evaluation is one of the important criteria to measure students' performance during their industrial training. All universities have their own assessment method. Majority of them use the concept of 'associated supervision' which involves assessment of the university (faculty supervisors) and industry (industry supervisor). One of the major issues related to assessment is the existence of a gap between both assessments (Phang et al., 2014). This is due lack of guidelines for assessing the industrial training. Based on Smith, (2003), the difficulties will arise when there are several parties conducting the assessment. Therefore, a process of empowering and strengthening those parties in assessment should be conducted to minimize the gap.

\section{METHODOLOGY}

To obtain the qualitative data, purposive sampling is used to identify interview participants who were included in the study. Selecting research participants according to specific qualities might increase the probability of obtaining the most relevant information to the study. There are two types of participant, the first are employers from industries and the second are industrial training coordinators from the Faculty of Engineering.

In this study, qualitative part becomes important when the interview protocols were done with experts which are experienced employers from established industries and industrial training coordinators from universities (Faculty of Engineering). The interview protocol instruments were built by the researcher based on previous studies and have been validated by three experts from the same field for each instrument. Thematic analysis was done to find the themes that will be discussed in the next section.

\section{RESULTS AND FINDINGS}

Identification of themes and sub-themes for the factors that influence trainees in improving their non-technical skill is guided by an industrial training module by Khairiyah et. al (2018). There are five essential factors in the module namely placement in the industry, training duration, assessment, type of training or task given and learning outcomes.

A. Issues in industrial training that influence trainees' non-technical skills development

Table 2 shows the themes of the interview findings based on assessment. There are five dimensions in this theme 
International Conference on Recents Advancements in Engineering and Technology (ICRAET-18) |15th and 16th March 2019|Siddhartha Institute of Technology \& Sciences, Telangana, India.

which are budget constraint for industrial visit, reliability issue on industry's assessment, different assessment between university and industry, not supervised by engineer and unprofessional supervision in the industry. Table 3 shows the summary of interview feedback for the issue based on assessment that influence trainees' non-technical skills development.

Next, Table 4 shows the themes of the interview findings based on students' placement. There are three dimensions in this theme which are large number of students, no allowance given and family-related company. Table 5 shows the summary of interview feedback for the issue based on placement that influence trainees' non-technical skills development.

Furthermore, Table 6 shows the themes of the interview findings based on students' training. There are two

Table 2: Themes of interview findings (Issues in Assessment) dimensions in this theme which are irrelevant training given and less support from company. Table 7 shows the summary of interview feedback for the issue based on training that influence trainees' non-technical skills development.

In addition, Table 8 shows the themes of the interview findings based on students' training duration. There are six dimensions in this theme which avoid students to receive manual-labour task, company requires longer training duration, bounded with academic calendar, not the main deciding factor for students' career, students require longer training duration and longer training does not equate to quality training. Table 9 shows the summary of interview feedback for the issue based on training duration that influence trainees' non-technical skills development.

\begin{tabular}{|c|c|c|c|}
\hline Supporting Data & $\begin{array}{c}\text { Particip } \\
\text { ants }\end{array}$ & Dimensions & Construct \\
\hline $\begin{array}{l}\text { If we have the manpower and budget, the industrial visitshould be } \\
\text { done twice on the students in the industry. But this also can be done to } \\
\text { the company that is just registered. } \\
\text { The budget problem is there, but we cannot save too much. We need to } \\
\text { think about the quality of supervisionand assessment. If there are too } \\
\text { many students to assess, maybethe lecturers do not have enough time } \\
\text { to assess thoroughly. } \\
\text { The industrial visit is abolished due to budgetconstraint If any } \\
\text { problem happens, the faculty supervisor whovolunteered to visit } \\
\text { students wouldnot get paid } \\
\text {...the visit will be substituted withemails, phone calls or video calls. } \\
\text { Industrialvisit is very important. But in our university, we need to } \\
\text { consider the costneeded, we limit it by preparing the schedule for } \\
\text { industrial visit. We also advicestudents not to apply placement that is } \\
\text { far from the university. } \\
\text {-.. proper schedule will help in minimizing the costofindustrialvisit. } \\
\text { The problem arises when the reliability of the assessment from the } \\
\text { industry is questionable. This is why there is no grade given to the } \\
\text { students. } \\
\text { organizations and supervisor positions. } \\
\text { assessments. They maybe don't know the scale difference in the given } \\
\text { forms. }\end{array}$ & $\begin{array}{l}\mathrm{L} 2, \mathrm{~L} 4, \mathrm{~L} \\
6, \mathrm{~L} 7, \mathrm{~L} 1 \\
0, \mathrm{~L} 11, \\
\mathrm{~L} 12\end{array}$ & $\begin{array}{l}\text { Reliability issue } \\
\text { on industry's } \\
\text { assessment }\end{array}$ & $\begin{array}{l}\text { Issue in } \\
\text { Assessment }\end{array}$ \\
\hline
\end{tabular}




\begin{tabular}{|c|c|c|}
\hline $\begin{array}{l}\text { Industrial supervisors can observe the students work every day. That is } \\
\text { why the marks distribution between industrial supervisor and faculty } \\
\text { supervisor is } 60 \% \text { and } 40 \% \text {. Furthermore, the form is easy to be } \\
\text { understood } \\
\text { If all universities have the same industrial training system, then the } \\
\text { assessment will be exact and uniform. If the training duration is too } \\
\text { short, the students do not have enough time to show their skills. }\end{array}$ & $\begin{array}{l}\mathrm{L} 2, \mathrm{~L} 6, \mathrm{~L} \\
7, \mathrm{~L} 8, \mathrm{~L} 9\end{array}$ & $\begin{array}{l}\text { Different } \\
\text { assessment } \\
\text { between } \\
\text { university and } \\
\text { industry }\end{array}$ \\
\hline $\begin{array}{l}\text { The students are reporting to the engineer, but they follow technician } \\
\text { while doing the task. In this case, they do lots of hands-on. } \\
\text { Their industrial supervisor can be manager, engineer or technician } \\
\text { For now, we do not state that only engineer can supervise the students. }\end{array}$ & L4,L11 & $\begin{array}{l}\text { Not supervised } \\
\text { by engineer }\end{array}$ \\
\hline $\begin{array}{l}\text { The problem arises when the students are supervised by several } \\
\text { supervisors in a company. They need to transfer from department to } \\
\text { another department. } \\
\text { I have received complaint from students when they are bullied by } \\
\text { supervisor. } \\
\text {...they are not receiving proper guidance from the supervisor. } \\
\text {..students are supervised by foreignworker.. }\end{array}$ & $\begin{array}{l}\mathrm{L1} 1, \mathrm{~L} 4, \mathrm{~L} \\
6, \mathrm{~L} 8, \mathrm{~L} 9, \\
\mathrm{~L} 10\end{array}$ & $\begin{array}{l}\text { Unprofessional } \\
\text { supervision in } \\
\text { industry }\end{array}$ \\
\hline
\end{tabular}

Table 3: Summary of Interview Feedback for the issue based on the factors that influence trainees' non-technical skills development (Assessment)

\begin{tabular}{|c|c|c|c|c|c|c|c|c|c|c|c|c|}
\hline \multirow[t]{2}{*}{ Sub-constructs } & \multicolumn{12}{|c|}{ Expert 2 (Industrial Training Coordinators) } \\
\hline & $\mathbf{L 1}$ & $\mathbf{L 2}$ & $\mathbf{L 3}$ & L4 & $\mathbf{L 5}$ & L6 & L7 & L8 & L9 & $\mathbf{L 1 0}$ & L11 & L12 \\
\hline $\begin{array}{l}\text { Budget Constraint for } \\
\text { Industrial Visit }\end{array}$ & & $\lambda$ & & 1 & & $\lambda$ & $\lambda$ & & & 1 & $\lambda$ & $\lambda$ \\
\hline $\begin{array}{l}\text { Reliability issue on } \\
\text { industry's assessment }\end{array}$ & & & & 1 & & & & & & & & \\
\hline $\begin{array}{l}\text { Different assessment } \\
\text { between university and } \\
\text { industry }\end{array}$ & & 1 & & & & 1 & 1 & 1 & 1 & & & \\
\hline $\begin{array}{l}\text { Not supervised by } \\
\text { engineer }\end{array}$ & & & & 1 & & & & & & & $\lambda$ & \\
\hline $\begin{array}{l}\text { Unprofessional } \\
\text { supervision in industry }\end{array}$ & 1 & & & 1 & & 1 & & 1 & 1 & 1 & & \\
\hline
\end{tabular}

Table 4: Themes of interview findings (Issues in Placement)

\begin{tabular}{|c|c|c|c|}
\hline Supporting Data & Participants & Dimensions & Construct \\
\hline $\begin{array}{l}\text { We have around } 400-500 \text { students that need to undergo industrial } \\
\text { training in a year. } \\
\text { When the number of students is large, there will be more challenges } \\
\text { in managing all the students to get quality company. }\end{array}$ & $\mathrm{L} 2, \mathrm{~L} 3, \mathrm{~L} 8$ & $\begin{array}{l}\text { Large number } \\
\text { of students }\end{array}$ & $\begin{array}{c}\text { Issues in } \\
\text { Placement }\end{array}$ \\
\hline $\begin{array}{l}\text { Students always complained there was no allowance given. } \\
\text { Students could be in trouble if there is no allowance at all. This } \\
\text { caused students to find placement near to their hometown. }\end{array}$ & $\mathrm{L} 2, \mathrm{~L} 4, \mathrm{~L} 9$ & $\begin{array}{c}\text { No allowance } \\
\text { given }\end{array}$ & \\
\hline $\begin{array}{l}\text {...students became undisciplined and irresponsibility when they } \\
\text { were training in the company that is related to their family. } \\
\text { s. a student whose father owns a business, students will be not } \\
\text { serious in their training. }\end{array}$ & L9 & $\begin{array}{c}\text { Family-related } \\
\text { company }\end{array}$ & \\
\hline
\end{tabular}


International Conference on Recents Advancements in Engineering and Technology (ICRAET-18) |15th and 16th March 2019|Siddhartha Institute of Technology \& Sciences, Telangana, India.

Table 5: Summary of Interview Feedback for the issue based on the factors that influence trainees' non-technical skills development (Placement)

\begin{tabular}{|l|l|l|l|l|l|l|l|l|l|l|l|l|}
\hline \multirow{2}{*}{ Sub-constructs } & \multicolumn{9}{|l|}{ Expert 2 (Industrial Training Coordinators) } \\
\cline { 2 - 13 } & L1 & L2 & L3 & L4 & L5 & L6 & L7 & L8 & L9 & L10 & L11 & L12 \\
\hline $\begin{array}{l}\text { Large number of } \\
\text { students }\end{array}$ & & 1 & 1 & & & & & / & & & & \\
\hline No allowance given & & 1 & & 1 & & & & & 1 & & & \\
\hline $\begin{array}{l}\text { Family-related } \\
\text { company }\end{array}$ & & & & & & & & & 1 & & & \\
\hline
\end{tabular}

Table 6: Themes of interview findings (Issues in Training)

\begin{tabular}{|c|c|c|c|}
\hline Supporting Data & Participants & Dimensions & Construct \\
\hline $\begin{array}{l}\text {...students are not receiving appropriate training and } \\
\text { sometimes they just sit and do nothing. } \\
\text {...the hope is the given training is suitable to the level of } \\
\text { students (degree). } \\
\text { We are disappointed when the student did not receive } \\
\text { training that they already stated in the schedule. }\end{array}$ & $\begin{array}{l}\text { L1,L4,L5,L6, } \\
\text { L7,L8, } \\
\text { L9,L10 }\end{array}$ & $\begin{array}{c}\text { Irrelevant } \\
\text { Training } \\
\text { Given }\end{array}$ & $\begin{array}{l}\text { Issues in } \\
\text { Training }\end{array}$ \\
\hline $\begin{array}{l}\text { The cooperation from company is very i mportant in training } \\
\text { the students. We feel sad when certain company make use of } \\
\text { the students to become the staff. } \\
\text { Based on my experience, not all companies cooperate with } \\
\text { us. Lucky students will get good company and supervisor. } \\
\text { We provide reply form to the company to give us training } \\
\text { schedule. But not all replied and some only replied } \\
\text { incomplete schedule. }\end{array}$ & $\begin{array}{l}\mathrm{L} 3, \mathrm{~L} 4, \mathrm{~L} 6, \mathrm{~L} 1 \\
0, \mathrm{~L} 11\end{array}$ & $\begin{array}{l}\text { Less support } \\
\text { from } \\
\text { company }\end{array}$ & \\
\hline
\end{tabular}

Table 7: Summary of Interview Feedback for the issue based on the factors that influence trainees' non-technical skills development (Training)

\begin{tabular}{|l|l|l|l|l|l|l|l|l|l|l|l|l|}
\hline \multicolumn{1}{|c|}{ Sub-constructs } & \multicolumn{7}{|c|}{ Expert 2 (Industrial Training Coordinators) } \\
\cline { 2 - 10 } & L1 & L2 & L3 & L4 & L5 & L6 & L7 & L8 & L9 & L10 & L11 & L12 \\
\hline $\begin{array}{l}\text { Irrelevant Training } \\
\text { Given }\end{array}$ & 1 & & & / & 1 & & 1 & 1 & 1 & 1 & & \\
\hline $\begin{array}{l}\text { Less Support from } \\
\text { Company }\end{array}$ & & & 1 & 1 & & 1 & & & & 1 & 1 & \\
\hline
\end{tabular}


Table 8: Themes of interview findings (Issues in Training Duration)

\begin{tabular}{|c|c|c|c|}
\hline Supporting Data & $\begin{array}{c}\text { Participant } \\
\text { s }\end{array}$ & Dimensions & Construct \\
\hline $\begin{array}{l}\text { If the training duration is too long, the company could } \\
\text { give manual labour task to the students. } \\
\text { If anything happens, it is only for } 10 \text { weeks. } \\
\text {...6 months of training is serious if the students only } \\
\text { get operator's tasks/ }\end{array}$ & $\begin{array}{l}\text { L2,L8,L9,L1 } \\
1, L 12\end{array}$ & $\begin{array}{c}\text { Avoid } \\
\text { students to } \\
\text { receive } \\
\text { manual } \\
\text { labour task }\end{array}$ & \multirow[t]{6}{*}{$\begin{array}{l}\text { Issues in } \\
\text { Training }\end{array}$} \\
\hline $\begin{array}{l}\text { The current duration is too short. A lot of companies } \\
\text { refuse students with short duration of training. } \\
\text { Companies requested at least } 3 \text { months or } 12 \text { weeks. } \\
\text { This is because they already have proper schedule for } \\
\text { industrial training students. } \\
\text { When many companies are requesting } 12 \text { weeks of } \\
\text { training, we should think of new mechanism in giving } \\
12 \text { weeks of industrial training to the students. }\end{array}$ & $\begin{array}{l}\text { L1,L2,L3,L5 } \\
\text {,L6,L7,L8,L } \\
10, L 11, L 12\end{array}$ & $\begin{array}{l}\text { Company } \\
\text { requires } \\
\text { longer } \\
\text { duration }\end{array}$ & \\
\hline $\begin{array}{l}\text { We understood the company policy when they need } \\
\text { students with only } 12 \text { weeks of duration. But we } \\
\text { cannot do anything if semester } 3 \text { only has } 10 \text { weeks. } \\
\text { Engineering students undergo industrial training at } \\
\text { their short semester which only consist } 12 \text { weeks. This } \\
\text { is after we shorten their final examinations schedule. } \\
\text { Faculty cannot give more training time due to } \\
\text { academic calendar that is fixed. }\end{array}$ & $\begin{array}{l}\text { L2,L3,L5,L6 } \\
\text {,L7,L8, } \\
\text { L10,L11, } \\
\text { L12 }\end{array}$ & $\begin{array}{l}\text { Bounded } \\
\text { with } \\
\text { Academic } \\
\text { Calendar }\end{array}$ & \\
\hline $\begin{array}{l}\text { My view is that the electrical engineering field is very } \\
\text { wide. Industrial training is not the career indicator for } \\
\text { the students. } \\
\text {...industrial training is not the place when students } \\
\text { learn about specific techniques. }\end{array}$ & $\begin{array}{l}\text { L4,L6,L7,L8 } \\
\text {,L10,L11,L1 } \\
2\end{array}$ & $\begin{array}{l}\text { Not the } \\
\text { Main } \\
\text { Deciding } \\
\text { Factor for } \\
\text { Students' } \\
\text { Career }\end{array}$ & \\
\hline $\begin{array}{l}\text { I always ask back the industry do they ready to hire } \\
\text { all the trainees. They said no. }\end{array}$ & & & \\
\hline $\begin{array}{l}\text {...10 weeks, which is not enough for engineering } \\
\text { student (laugh). } \\
\text {...8 weeks is not enough, and we want our students go } \\
\text { more longer time. } \\
\text { For me, the optimum time for industrial training is } 6 \\
\text { months. Company requires time to train the students } \\
\text { and to assess the students' performance. }\end{array}$ & $\begin{array}{l}\text { L1,L2,L3,L5 } \\
\text {,L6,L7,L8, } \\
\text { L9 }\end{array}$ & $\begin{array}{l}\text { Students } \\
\text { Require } \\
\text { Longer } \\
\text { Training } \\
\text { Duration }\end{array}$ & \\
\hline $\begin{array}{l}\text {...they give allowances, but they ask the students to do } \\
\text { a lot of thing. } \\
\text { Wow, } 8 \text { months? (surprise). They should know what } \\
\text { kind of training is given to the students. } \\
\text {... are the students receiving the same experience in } \\
\text { the } 8 \text { months duration of training? We know that the } \\
\text { industries are different and maybe our students do not } \\
\text { get proper training. }\end{array}$ & $\begin{array}{l}\text { L2,L3,L4,L7 } \\
\text {,L8,L10 }\end{array}$ & $\begin{array}{c}\text { Longer } \\
\text { training does } \\
\text { not equate to } \\
\text { quality } \\
\text { training }\end{array}$ & \\
\hline
\end{tabular}


International Conference on Recents Advancements in Engineering and Technology (ICRAET-18) |15th and 16th March 2019|Siddhartha Institute of Technology \& Sciences, Telangana, India.

Table 9: Summary of Interview Feedback for the issue based on the factors that influence trainees' non-technical skills development (Training Duration)

\begin{tabular}{|l|c|c|c|c|c|c|c|c|c|c|c|c|}
\hline \multirow{2}{*}{ Sub-constructs } & \multicolumn{7}{|c|}{ Expert 2 (Industrial Training Coordinators) } \\
\cline { 2 - 12 } & L1 & L2 & L3 & L4 & L5 & L6 & L7 & L8 & L9 & L10 & L11 & L12 \\
\hline $\begin{array}{l}\text { Avoid students to } \\
\text { receive manual } \\
\text { labour task }\end{array}$ & & $\lambda$ & & & & & & $\lambda$ & $\lambda$ & & $\lambda$ & $\lambda$ \\
\hline $\begin{array}{l}\text { Company requires } \\
\text { longer training } \\
\text { duration }\end{array}$ & $\lambda$ & $\lambda$ & $\lambda$ & & $\lambda$ & $\lambda$ & $\lambda$ & $\lambda$ & & $\lambda$ & $\lambda$ & $\lambda$ \\
\hline $\begin{array}{l}\text { Bounded with } \\
\text { Academic Calendar }\end{array}$ & & $\lambda$ & $\lambda$ & & $\lambda$ & $\lambda$ & $\lambda$ & $\lambda$ & & $\lambda$ & $\lambda$ & $\lambda$ \\
\hline $\begin{array}{l}\text { Not the Main } \\
\text { Deciding Factor for } \\
\text { Students' Career }\end{array}$ & & & & $\lambda$ & & $\lambda$ & $\lambda$ & $\lambda$ & & $\lambda$ & $\lambda$ & $\lambda$ \\
\hline $\begin{array}{l}\text { Students Require } \\
\text { Longer Training } \\
\text { Duration }\end{array}$ & $\lambda$ & $\lambda$ & $\lambda$ & & $/$ & $\lambda$ & $\lambda$ & $\lambda$ & $\lambda$ & & & \\
\hline $\begin{array}{l}\text { Longer training } \\
\text { does not equate to } \\
\text { quality training }\end{array}$ & & $\lambda$ & $\lambda$ & $\lambda$ & & & $\lambda$ & $\lambda$ & & $\lambda$ & & \\
\hline
\end{tabular}

B.Faculty's resolutions towards minimizing issues in industrial training.

Issues in industrial training cannot be completely abolished but the faculty is trying very hard in minimizing them. Below tables show the finding regarding to this matter. Table 10 shows the theme of the interview findings based on assessment. There are four dimensions in this theme which are industrial visit management due to budget constraint, rubric forms are based on industry's trend and EAC, user-friendly rubric forms for industrial supervisor and evaluation is graded to be included in CGPA. Table 11 shows the summary of interview feedback for faculty's resolutions towards minimizing issues based on assessment.

Table 12 shows the theme of the interview findings based on students' placement. There are three dimensions in this theme which are to avoid irrelevant industry, database control and blacklist company with issue. Table 13 shows the summary of interview feedback for faculty's resolutions towards minimizing issues based on students' placement.

Table 14 shows the theme of the interview findings based on training duration. There is one dimension in this theme which is based on EAC requirement. Table 15 shows the summary of interview feedback for faculty's resolutions towards minimizing issues based on training duration.

Table 16 shows the theme of the interview findings based on training. There are three dimensions in this theme which are focusing on non-technical skills and engineering exposure, pre-industrial training program and request training schedule from the company. Table 17 shows the summary of interview feedback for faculty's resolutions towards minimizing issues based on training. 
Table 10: Themes of interview findings (Faculty's Resolutions towards Minimizing Issues based on Assessment)

\begin{tabular}{|c|c|c|c|}
\hline Supporting Data & Participants & Dimensions & Construct \\
\hline $\begin{array}{l}\text {...we arrange the lecturer to visit a number a student } \\
\text { at the same time. We only consider students who are } \\
\text { training in peninsular of Malaysia only. } \\
\text {... if students undergo training in Sabah or Sarawak, } \\
\text { we don't visit them, but we do video call or Skype. } \\
\text {... maybe phone calls or emails if the location is too } \\
\text { far. } \\
\text { We have made schedule for industrial visit to cut the } \\
\text { cost. }\end{array}$ & $\begin{array}{l}\text { L1,L2,L3,L6,L9,L1 } \\
\text { 0,L11,L12 }\end{array}$ & $\begin{array}{c}\text { Industrial } \\
\text { Visit } \\
\text { Management } \\
\text { due to } \\
\text { budget } \\
\text { constraint }\end{array}$ & $\begin{array}{c}\text { Faculty's } \\
\text { Resolutions } \\
\text { towards } \\
\text { Minimizing } \\
\text { Issues based } \\
\text { on } \\
\text { Assessment }\end{array}$ \\
\hline $\begin{array}{l}\text {...the role of industrial training coordinator is to } \\
\text { make sure all the forms are suitable to be used or } \\
\text { need improvement. } \\
\text {... forms are constructed based on Course Learning } \\
\text { Outcomes (CLO) that are fixed by faculty. } \\
\text {...the form will be updated if needed. } \\
\text { The rubric forms are written in detail to reduce the } \\
\text { subjectivity. There are updated based on Industrial } \\
\text { Advisor Panel (IAP) comments. }\end{array}$ & $\begin{array}{l}\text { L1,L2,L3,L4,L6,L7, } \\
\text { L8,L9,L10,L11 }\end{array}$ & $\begin{array}{l}\text { Rubric forms } \\
\text { are based on } \\
\text { industry's } \\
\text { trend and } \\
\text { EAC }\end{array}$ & \\
\hline $\begin{array}{l}\text { Like I've said before, we prepare user-friendly forms. } \\
\text {...the sentences are simplified to make it is } \\
\text { understandable and can be done without industrial } \\
\text { visit. } \\
\text { The rubric is very detail and complete. We have done } \\
\text { lots of review. While visit, we will guide the industrial } \\
\text { supervisor to rate. } \\
\text { The questions are easy to understand. But the } \\
\text { industrial supervisor must be the one who students } \\
\text { report directly to him/her. The experience and } \\
\text { knowledge about the students are very important to } \\
\text { assure the reliability of the evaluation. }\end{array}$ & L2,L4,L9,L11 & $\begin{array}{l}\text { User- } \\
\text { friendly } \\
\text { rubric forms } \\
\text { for Industrial } \\
\text { Supervisor }\end{array}$ & \\
\hline $\begin{array}{l}\text { Total credits for internship in our university is } 14 \\
\text { credits and we have grade to be included in CGPA. } \\
\text { Other universities only apply pass-fail basis. } \\
\text { When grade is applied, student will be more serious } \\
\text { and hardworking to be excel in their internship. } \\
\text { Starting from this year, we apply grade in industrial } \\
\text { training based on students' logbook, report, } \\
\text { presentation and assessment from industry. }\end{array}$ & L9,L12 & $\begin{array}{l}\text { Evaluation is } \\
\text { graded to be } \\
\text { included in } \\
\text { CGPA }\end{array}$ & \\
\hline
\end{tabular}


International Conference on Recents Advancements in Engineering and Technology (ICRAET-18) |15th and 16th March 2019|Siddhartha Institute of Technology \& Sciences, Telangana, India.

Table11: Summary of Interview Feedback for Faculty's Resolutions towards Minimizing Issues Based on Factors (Assessment)

\begin{tabular}{|l|c|c|c|c|c|c|c|c|c|c|c|c|}
\hline \multirow{2}{*}{ Sub-constructs } & \multicolumn{10}{|c|}{ Expert 2 (Industrial Training Coordinators) } \\
\cline { 2 - 11 } & L1 & L2 & L3 & L4 & L5 & L6 & L7 & L8 & L9 & L10 & L11 & L12 \\
\hline $\begin{array}{l}\text { Industrial Visit } \\
\text { Management due to } \\
\text { budget constraint }\end{array}$ & $\lambda$ & $\lambda$ & $\lambda$ & & & $\lambda$ & $\lambda$ & $\lambda$ & $\lambda$ & $\lambda$ & $\lambda$ & $\lambda$ \\
\hline $\begin{array}{l}\text { Rubric forms are } \\
\text { based on industry's } \\
\text { trend and EAC }\end{array}$ & $\lambda$ & $\lambda$ & $\lambda$ & $\lambda$ & & $\lambda$ & $\lambda$ & $\lambda$ & $\lambda$ & $\lambda$ & $\lambda$ & \\
\hline $\begin{array}{l}\text { User-friendly rubric } \\
\text { forms for Industrial } \\
\text { Supervisor }\end{array}$ & & $\lambda$ & & $\lambda$ & & & & & $\lambda$ & & $\lambda$ & \\
\hline $\begin{array}{l}\text { Evaluation is graded } \\
\text { to be included in } \\
\text { CGPA }\end{array}$ & & & & & & & & & $\lambda$ & & & $\lambda$ \\
\hline
\end{tabular}

Table 12: Construct of interview findings (Faculty's Resolutions towards Minimizing Issues based on Placement)

\begin{tabular}{|c|c|c|c|}
\hline \begin{tabular}{|l} 
Supporting Data \\
\end{tabular} & Participants & Dimensions & Construct \\
\hline $\begin{array}{l}\text {... system in our university is developed to make sure } \\
\text { students can get their placements easily. In the system, } \\
\text { the database of companies based on faculty may help } \\
\text { students in finding placement for their industrial } \\
\text { training. } \\
\text { It's already enough if the students seriously find the } \\
\text { company in the list. This is because we already sorted } \\
\text { the company based on programmes. } \\
\text { We upgraded the system from manual to automatic. } \\
\text {...the database is from the students records before. For } \\
\text { now, there are around } 400 \text { companies in the database. }\end{array}$ & $\begin{array}{l}\text { L3,L5,L8,L9,L10, } \\
\text { L11 }\end{array}$ & $\begin{array}{c}\text { Avoid } \\
\text { Irrelevant } \\
\text { Industry }\end{array}$ & $\begin{array}{c}\text { Faculty's } \\
\text { Resolutions } \\
\text { towards } \\
\text { Minimizing } \\
\text { Issues } \\
\text { based on } \\
\text { Placement }\end{array}$ \\
\hline $\begin{array}{l}\text { We give permission to students who want to apply } \\
\text { company which does not available in the database. } \\
\text { But the students should register the company first. } \\
\text { That's why the number of companies increase every } \\
\text { year. } \\
\text { If the company does not available in the database, only } \\
\text { industrial training coordinator has the authorization to } \\
\text { include the company in the database. Students need to } \\
\text { fill a form. }\end{array}$ & $\begin{array}{l}\text { L1,L3,L4,L5,L6,L } \\
\text { 7,L8 }\end{array}$ & $\begin{array}{c}\text { Database } \\
\text { Control }\end{array}$ & \\
\hline $\begin{array}{l}\text { Irrelevant companies will be blacklisted which students } \\
\text { cannot apply anymore. } \\
\text {...we can't control the company. If a company is } \\
\text { problematic, we just blacklist it. Future students are } \\
\text { not encouraged to apply blacklisted company. } \\
\text { If we receive negative comments from students, we will } \\
\text { blacklist the company. }\end{array}$ & $\begin{array}{l}\text { L1,L2,L4,L5,L6,L } \\
\text { 7,L9,L10 }\end{array}$ & $\begin{array}{l}\text { Blacklist } \\
\text { company } \\
\text { with issue }\end{array}$ & \\
\hline
\end{tabular}


Table 13: Summary of Interview Feedback for Faculty's Resolutions towards Minimizing Issues Based on Factors (Placement)

\begin{tabular}{|l|c|c|c|c|c|c|c|c|c|c|c|c|}
\hline \multirow{2}{*}{ Sub-constructs } & \multicolumn{10}{|c|}{ Expert 2 (Industrial Training Coordinators) } \\
\cline { 2 - 14 } & L1 & L2 & L3 & L4 & L5 & L6 & L7 & L8 & L9 & L10 & L11 & L12 \\
\hline $\begin{array}{l}\text { Avoid Irrelevant } \\
\text { Industry }\end{array}$ & & & $/$ & & $/$ & & & $/$ & $/$ & $/$ & $/$ & \\
\hline Database Control & $/$ & & $/$ & $/$ & $/$ & $/$ & $/$ & $/$ & & & & \\
\hline $\begin{array}{l}\text { Blacklist company } \\
\text { with issue }\end{array}$ & $/$ & $/$ & & $/$ & $/$ & $/$ & $/$ & & $/$ & $/$ & & \\
\hline
\end{tabular}

Table 14: Themes of interview findings (Faculty's Resolutions towards Minimizing Issues based on Training Duration)

\begin{tabular}{|c|c|c|c|}
\hline Supporting Data & Participants & Dimensions & Construct \\
\hline $\begin{array}{l}10 \text { weeks of training is enough because it is fixed } \\
\text { by EAC and the aim of industrial training is to } \\
\text { expose students to engineering field. } \\
\text {...we give } 10 \text { weeks. EAC only requires students } \\
\text { to undergo minimum } 8 \text { weeks of industrial } \\
\text { training. If anything happens to the students, the } \\
2 \text { weeks could cover. } \\
\text { In my view, we just follow the EAC requirement } \\
\text { which is } 8 \text { weeks. EAC must did a research } \\
\text { before they fixed to } 8 \text { weeks. }\end{array}$ & $\begin{array}{l}\text { L2,L3,L4,L5,L6,L7, } \\
\text { L8,L9,L10,L11 }\end{array}$ & $\begin{array}{l}\text { Based on } \\
\text { EAC } \\
\text { requirement }\end{array}$ & $\begin{array}{c}\text { Faculty's } \\
\text { Resolutions } \\
\text { towards } \\
\text { Minimizing } \\
\text { Issues } \\
\text { based on } \\
\text { Training } \\
\text { Duration }\end{array}$ \\
\hline
\end{tabular}

Table 15: Summary of Interview Feedback for Faculty's Resolutions towards Minimizing Issues Based on Factors (Training Duration)

\begin{tabular}{|l|c|c|c|c|c|c|c|c|c|c|c|c|}
\hline \multirow{3}{*}{ Sub-constructs } & \multicolumn{10}{|c|}{ Expert 2 (Industrial Training Coordinators) } \\
\cline { 2 - 12 } & L1 & L2 & L3 & L4 & L5 & L6 & L7 & L8 & L9 & L10 & L11 & L12 \\
\hline $\begin{array}{l}\text { Based on EAC } \\
\text { requirement }\end{array}$ & & & $\lambda$ & $\lambda$ & $\lambda$ & $\lambda$ & $\lambda$ & $\lambda$ & 1 & 1 & 1 & \\
\hline
\end{tabular}


International Conference on Recents Advancements in Engineering and Technology (ICRAET-18) |15th and 16th March 2019|Siddhartha Institute of Technology \& Sciences, Telangana, India.

Table 16: Themes of interview findings (Faculty's Resolutions towards Minimizing Issues based on Training)

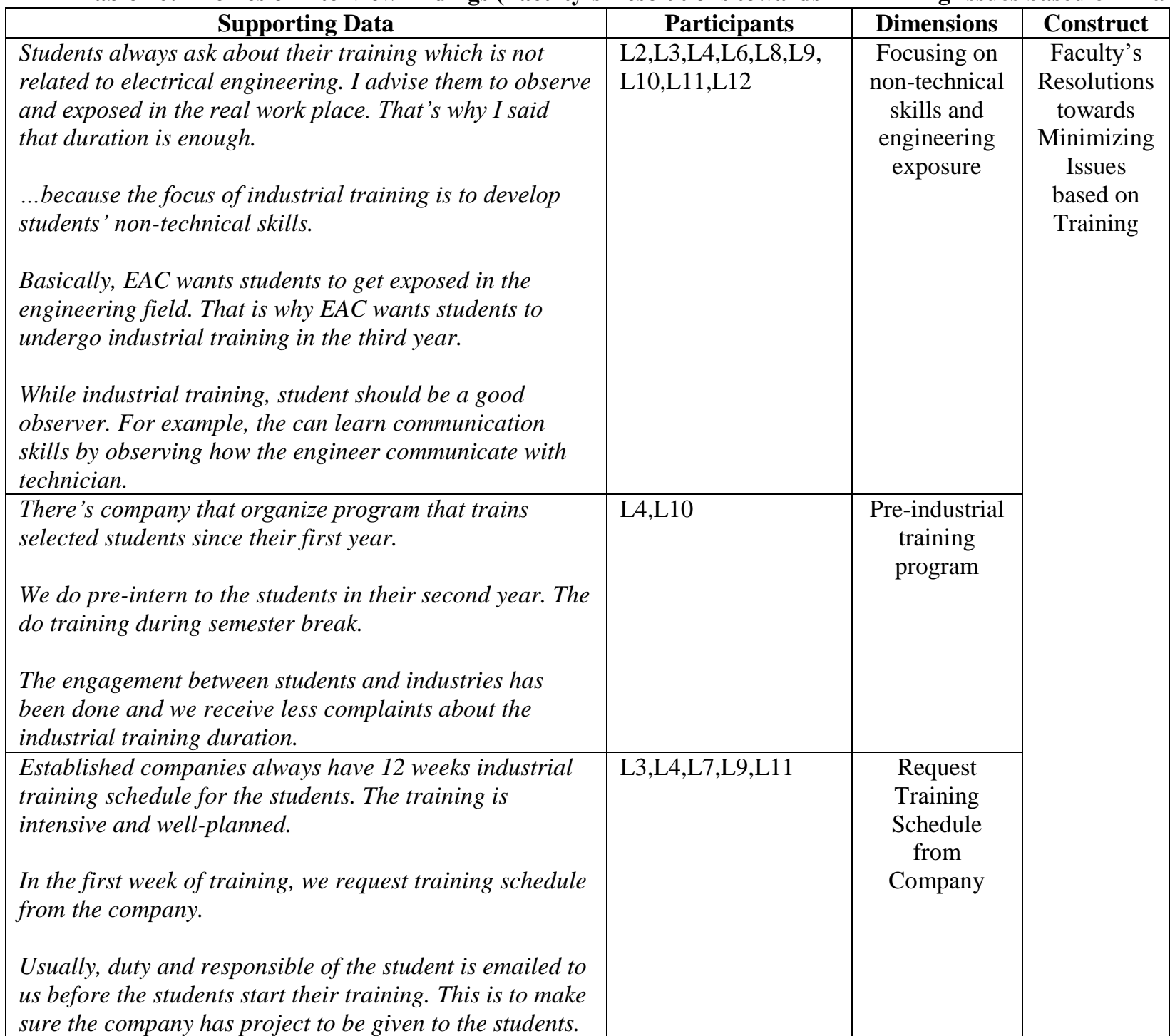

Table 17: Summary of Interview Feedback for Faculty's Resolutions towards Minimizing Issues Based on Factors (Training)

\begin{tabular}{|l|c|c|c|c|c|c|c|c|c|c|c|c|}
\hline \multirow{2}{*}{ Sub-constructs } & \multicolumn{8}{|c|}{ Expert 2 (Industrial Training Coordinators) } \\
\cline { 2 - 11 } & L1 & L2 & L3 & L4 & L5 & L6 & L7 & L8 & L9 & L10 & L11 & L12 \\
\hline $\begin{array}{l}\text { Focusing on non- } \\
\text { technical skills and } \\
\text { engineering } \\
\text { exposure }\end{array}$ & & $\lambda$ & $\lambda$ & $\lambda$ & & $\lambda$ & & $\lambda$ & $\lambda$ & $\lambda$ & $\lambda$ & \\
\hline $\begin{array}{l}\text { Pre-industrial } \\
\text { training program }\end{array}$ & & & & $\lambda$ & & & & & & $\lambda$ & & \\
\hline $\begin{array}{l}\text { Request Training } \\
\text { Schedule from } \\
\text { Company }\end{array}$ & & & $\lambda$ & $\lambda$ & & & $\lambda$ & & $\lambda$ & & $\lambda$ & \\
\hline
\end{tabular}


Table 18: Themes of interview findings (Faculty's Resolutions towards Minimizing Issues based on Faculty Supports)

\begin{tabular}{|c|c|c|c|}
\hline Supporting Data & Participants & $\begin{array}{c}\text { Dimension } \\
\mathbf{s}\end{array}$ & Construct \\
\hline $\begin{array}{l}\text { All the application, acceptation and rejection } \\
\text { letters can be auto generated from the system. } \\
\text { All the documents are digitized, no more papers } \\
\text { and files. } \\
\text { The usage of e-log book will reduce the paper } \\
\text { dumping where all the information is kept online } \\
\text { make it is easy to access. This is very important } \\
\text { for audit. }\end{array}$ & $\begin{array}{l}\text { L3,L4,L6,L7,L8,L } \\
12\end{array}$ & $\begin{array}{l}\text { Industrial } \\
\text { Training } \\
\text { System }\end{array}$ & $\begin{array}{l}\text { Faculty's } \\
\text { Resolutions } \\
\text { towards } \\
\text { Minimizing } \\
\text { Issues } \\
\text { based on } \\
\text { Faculty } \\
\text { Support }\end{array}$ \\
\hline $\begin{array}{l}\text { There are two briefings will be given to the } \\
\text { students. First one is more about placement. } \\
\text {..two briefings will be held. After the first } \\
\text { briefing, the students are starting to find their } \\
\text { placements. } \\
\text { Beside briefing, we have a website that contain } \\
\text { all the information needed by students. }\end{array}$ & $\begin{array}{l}\text { L2,L3,L4,L6,L7,L } \\
8, \\
\text { L12 }\end{array}$ & $\begin{array}{l}\text { Briefing } \\
\text { Sessions }\end{array}$ & \\
\hline $\begin{array}{l}\text { We always give advice if students are facing } \\
\text { small problems in the industry to stay for } 10 \\
\text { weeks. } \\
\text { If students complaint there is no task given while } \\
\text { training, we advise the students to meet the } \\
\text { technician or other staff to learn anything that } \\
\text { they could. }\end{array}$ & L3,L4,L6,L9,L10 & $\begin{array}{l}\text { Advice and } \\
\text { Guidance }\end{array}$ & \\
\hline $\begin{array}{l}\text { Yes, students can change the place if serious } \\
\text { thing happens. But the need to prepare several } \\
\text { letters and through dean. } \\
\text { We can help students if they have problem and if } \\
\text { they want to change company. But they must do it } \\
\text { fast. } \\
\text { We will do an investigation if students complaint. } \\
\text { If the issue is big, we will allow students to } \\
\text { change the company. }\end{array}$ & $\begin{array}{l}\text { L3,L4,L5,L6,L10, } \\
\text { L11 }\end{array}$ & $\begin{array}{l}\text { Placement } \\
\text { Change } \\
\text { Procedure }\end{array}$ & \\
\hline $\begin{array}{l}\text { We have mailing list that is used to disseminate } \\
\text { information to the students. We also have special } \\
\text { Facebook for industrial training. } \\
\text { Official email is created to communicate with the } \\
\text { students. } \\
\text {...Whatsapp, phone call or emails directly to me. }\end{array}$ & $\begin{array}{l}\text { L5,L7.L8,L11,L1 } \\
2\end{array}$ & $\begin{array}{c}\text { Feedback } \\
\text { Medium }\end{array}$ & \\
\hline
\end{tabular}


International Conference on Recents Advancements in Engineering and Technology (ICRAET-18) |15th and 16th March 2019|Siddhartha Institute of Technology \& Sciences, Telangana, India.

Table 19: Summary of Interview Feedback for Faculty's Resolutions towards Minimizing Issues Based on Factors (Faculty Supports)

\begin{tabular}{|l|c|c|c|c|c|c|c|c|c|c|c|c|}
\hline \multirow{2}{*}{ Sub-constructs } & \multicolumn{10}{|c|}{ Expert 2 (Industrial Training Coordinators) } \\
\cline { 2 - 16 } & L1 & L2 & L3 & L4 & L5 & L6 & L7 & L8 & L9 & L10 & L11 & L12 \\
\hline $\begin{array}{l}\text { Industrial Training } \\
\text { System }\end{array}$ & & & 1 & 1 & 1 & 1 & 1 & 1 & & & & 1 \\
\hline Briefing Sessions & & 1 & 1 & 1 & & 1 & 1 & 1 & & & & 1 \\
\hline $\begin{array}{l}\text { Advice and } \\
\text { Guidance }\end{array}$ & & & 1 & 1 & & 1 & & & 1 & 1 & & \\
\hline $\begin{array}{l}\text { Placement Change } \\
\text { Procedure }\end{array}$ & & & 1 & 1 & 1 & 1 & & & & 1 & 1 & \\
\hline Feedback Medium & & & 1 & 1 & 1 & 1 & 1 & 1 & & & 1 & 1 \\
\hline
\end{tabular}

Table 18 shows the themes of the interview findings based on faculty supports. There are five dimensions in this theme which are industrial training system, briefing sessions, advice and guidance, placement change procedure and feedback medium. Table 19 shows the summary of interview feedback for faculty's resolutions towards minimizing issues based on faculty supports.

\section{DISCUSSIONS AND CONCLUSSIONS}

The issues and challenges in industrial training cannot be completely diminished but can be reduced with proper procedures. When critical issues and problems happen to students, these can lead to considerable frustration among students who are likely to feel that they are not learning the required job-specific and general job skills during their industrial training (Pillai et al., 2012). However, faculty is always trying the best in finding resolutions toward minimizing the issues.

Assessment is the factor that having a lot of issues. This is agreed by Shariff \& Muhamad (2010) in their qualitative study where there were insufficient documentation and no standard or formal evaluation from the host company. Based on this study, it is proved that this issue is still happening now. In addition, faculty is having budget constraint issues that might be not students will be visited by faculty's supervisor. If this happens, the assessment to the student can be doubted. In minimizing this issue, the faculty has done industrial visit management by preparing intensive schedule to make sure the budget can be reduced. However, there is still having students that is not visited by faculty supervisor. For example, for students who do their training far from university. Furthermore, reliability issue on industry's assessment is questionable because the industry supervisor might not understand the questions to rate the students. For the resolution, faculty is making user-friendly forms with detail explanations to reduce the subjectivity of industry faculty's assessments.

Secondly, placement issue happens when faculty needs to manage a large number of students every year to undergo industrial training per year. As resolution, the manual system that is practiced before has been change to automatic system. Manual system is very complicated and time consuming if faculty needs to manage many students at one time (Jaafar et al., 2018). Automatic system is very important and can be the solution for this issue. The automatic system is used for letters generation, placement and assessment. In addition, the issue arises when the students do not receive allowance at all that causing students to find company that is near to their hometown. Based on finding, a lot of students underwent industrial training near to their hometown to reduce daily cost. In order to assure students will get company that is related to their field of study, faculty has a database which consist list of companies that can be chosen by the students. Besides, the problematic company will be blacklisted and cannot be applied by the students anymore.

Thirdly, the training issue is very important when there are some student's complaints the given task is not relevant to the electrical engineering field and sometime the students are asked to do lower-level task that is not suitable to students. To reduce that, faculty requests the training schedule from the company to make sure appropriate training is given to the students. Furthermore, the given task is focusing more on non-technical skills and students need to do a lot of observations.

Finally, most of university provides 8-12 weeks of industrial training for engineering students but there is one private university in Malaysia gives 28 weeks of industrial training to its engineering students. Based in the findings, faculties which gives 8-12 weeks of training claimed that duration is good enough for students to expose to engineering field even though companies and students themselves ask for longer duration. The industrial training committee afraid that students will receive irrelevant task for longer duration of industrial training. These reasons are based on EAC that has fixed minimum only 8 weeks duration given to engineering students undergo industrial training (Engineering Program Accreditation Manual, 2018)

\section{ACKNOWLEDGMENT}

We would like to thank School of Graduate Studies (SPS), UTM for assisting this study financially through Zamalah Scholarship

\section{REFERENCES}

1. G. O. Young, "Synthetic structure of industrial plastics (Book style with Ayob, A., Osman, S. A., Omar, M. Z., Jamaluddin, N., Kofli, N. T., \& Johar, S. (2013). 
Industrial Training as Gateway to Engineering Career: Experience Sharing. Procedia - Social and Behavioral Sciences, 102(Ifee 2012), 48-54. https://doi.org/10.1016/j.sbspro.2013.10.712

2. Azmi, A. N., Kamin, Y., Noordin, M. K., \& Nasir, A. N. M. (2018). Towards industrial revolution 4.0: employers' expectations on fresh engineering graduates. International Journal of Engineering \& Technology, 7(4.28), $267-272$. https://doi.org/10.14419/ijet.v7i4.28.22593

3. Bhurtun, C., Jahmeerbacus, I., Oolun, K., \& Feliachi, A (1999). Short-term practical training for electrical engineering undergraduates. IEEE Transactions on Education, $\quad 42(2)$,

109-113. https://doi.org/10.1109/13.762938

4. Binti Jaafar, A. N., Binti Rohafauzi, S., Binti Md Enzai, N. I., Bin Mohd Fauzi, F. D. H., Binti Nik Dzulkefli, N. N. S., \& Bin Amron, M. T. (2018). Development of internship monitoring and supervising web-based system. IEEE Student Conference on Research and Development: Inspiring Technology for Humanity, SCOReD 2017 . Proceedings, 2018-Janua, 193-197. https://doi.org/10.1109/SCORED.2017.8305395

5. Engineering Accreditation Council Manual, 2018. Available online at http://www.bem.org.com.

6. Hanapi, Z., Nordin, M. S., \& Khamis, A. (2015). Challenges Faced by Engineering Lecturers in Integrating Technical and Employability Skills in the Curriculum: A Case Study in Community College, Malaysia. International Journal of Social Science and Humanity, 5(5), 483-486. https://doi.org/10.7763/IJSSH.2015.V5.504

7. Husain, M. Y., Rasul, M. S., Mustapha, R., Malik, S. A., Amnah, R., \& Rauf, A. (2013). Jurnal Teknologi Full paper Tahap Kemahiran Employability Pelajar Kejuruteraan dari Perspektif, 1, 31-39.

8. Jamil, N. A., Shariff, S. M., \& Abu, Z. (2013). Students' Practicum Performance of Industrial Internship Program. Procedia - Social and Behavioral Sciences, 90, 513-521. https://doi.org/10.1016/j.sbspro.2013.07.121

9. Khairiyah, M. Y., et. al. (2018). Scenario Research on Industrial Training/Practicum in Malaysian HIgher Learning Institutions. Higher Education Leadership Academy (AKEPT), Ministry of Higher Education Malaysia.

10. Kucel, A., Róbert, P., Buil, M., \& Masferrer, N. (2016). Entrepreneurial Skills and Education-Job Matching of Higher Education Graduates. European Journal of Education, 51(1), 73-89. https://doi.org/10.1111/ejed.12161

11. Laguador, J. (2013). Engineering Students' Academic and on-the-Job Training Performance Appraisal Analysis. International Journal of E-Education, eBusiness, e-Management and e-Learning, 3(4), 4-8. https://doi.org/10.7763/IJEEEE.2013.V3.245

12. Muhammad Khair, N., \& et al. (2016). Framework for Project-Based Learning ( PjBL ) in Providing Real World Experience for Electrical Engineering Students Framework for Project-Based Learning ( PjBL ) in Providing Real World Experience for Electrical Engineering Students. Applied Mathematic and Information Sciences, (August).

13. Noordin, M. K. (2014). Project-Based Learning (PjBL) for non-Technical Skills.

14. Osman, S. A., Khoiry, M. A., Rahman, N. A., Rahni, A. A. A., Mansor, M. R. A., Nordin, D., \& Johar, S. (2016). The effectiveness of industrial training from the perspective of students of the civil and structure engineering department. Journal of Engineering Science and Technology, 11(Special Issue onpendidikankejuruteraandanalambina), 1-12.
15. Phang, F. A., Yusof, K. M., Saat, M. M., \& Yusof, N. M (2014). Perceptions of engineering students on industrial training in Malaysia, (JULY), 1-6. https://doi.org/10.5339/qproc.2014.wcee2013.20

16. Pillai, S., Khan, M. H., Syahirah, I., \& Raphael, S. (2012). Enhancing employability through industrial training in the Malaysian context, 187-204. https://doi.org/10.1007/s10734-011-9430-2

17. Ramlee Mustapha, ., Faridah Karim, ., Ruhizan Mohd Yasin, ., Norzaini Azman, ., Hamidah Yamat, ., Abdul Wahab Muhammad, ., \& Sobri Takriff, . (2008). KEconomy and Globalisation-Are our student ready? Jurnal Personalia Pelajar, 11(June), 1-23.

18. Rao, M. S. (2014). Enhancing employability in engineering and management students through soft skills. Industrial and Commercial Training, 46(1), 42-48 https://doi.org/10.1108/ICT-04-2013-0023

19. Rasul, M. S., Abd Rauf, R. A., Mansor, A. N., \& Puvanasvaran, A. P. (2012). Employability skills assessment tool development. International Education Studies, 5(5), 43-56. https://doi.org/10.5539/ies.v5n5p43

20. Rasul, M. S., Rauf, R. A. A., \& Nor, A. R. M. (2014). Future Employability Skills Sets for Manufacturing Industries. International Education Studies, 7(10), 138144. https://doi.org/10.5539/ies.v7n10p138

21. Renganathan, S., Ambri, Z., Abdul, B., \& Li, C. S (2013). Students perception of industrial internship programme. https://doi.org/10.1108/00400911211210288

22. Shariff, S. M., \& Muhamad, M. (2010). Learning in an Industrial Practicum Training Program : A Case Study in a Public University in Malaysia. Sariwati, 11(11), 13611368.

23. Smith, P. J. (2003). Workplace Learning and Flexible Delivery. Review of Educational Research, 73(1), 53-88. https://doi.org/10.3102/00346543073001053

24. Tapper *, J. (2004). Student perceptions of how critical thinking is embedded in a degree program. Higher Education Research \& Development, 23(2), 199-222. https://doi.org/10.1080/0729436042000206663

25. Yusof, N. A., Mohd Fauzi, S. N. F., Zainul Abidin, N., \& Awang, H. (2013). Improving graduates' employability skills through industrial training: Suggestions from employers. Journal of Education and Practice, 4(4), 23 29.

26. Zaharim, A., Yusoff, Y., Omar, M. Z., \& Mohamed, A. (2009). Perceptions and Expectation Toward Engineering Graduates by Employers: A Malaysian Study Case. WSEAS TRANSACTION on Advances in Engineering Education, 6(9), 296-305 